Canadian Journal of Disability Studies

Published by the Canadian Disability Studies Association Association Canadienne des Études sur l'Incapacité

Hosted by The University of Waterloo

www.cjds.uwaterloo.ca

This document has been made accessible and PDF/UA compliant by Accessibil-IT Inc. For more information go to http://www.accessibilit.com 


\section{Songs From the Dairy Section: Working with Disability \& Dignity}

"The idea of duty in one's calling prowls about in our lives like the ghost of dead religious beliefs" (Weber, 1958, p. 182).

I clutch the corner of the sticky rubber mat. Turning my face, I shield my eyes and mouth. The spray cloud of neon cleaning solution fills the room. We're in a damp, thousand-square-foot community fitness center. The stench of sweat and feet fills the air.

Twenty-one year old Mary ${ }^{1}$ works here as the gym's Yoga Mat Sanitizer. The gym staff invented this job and title for her. Each week I help Mary navigate her work responsibilities and procedures. The gym hired Mary to work one day per week, maximum. On that day she has a one-hour shift, and she earns ten dollars per hour before taxes. This is Mary's official list of duties: collect all of the yoga mats in the gym, hang them up, spray them down, wipe them off, put them away. Mary has multiple impairments, and her job entails much more than this list. Like a second shift, Mary's added workload includes tasks for which she is neither acknowledged, nor paid.

Mary has to get herself to and from work. She must sign in. She is required to attend to others in the gym as she collects all of the mats. In order to get herself to the gym before each shift, Mary walks three miles from home. She checks her watch every few minutes, because doing that helps her be sure to arrive ten minutes before her shift officially begins. That tenminute period is our time to catch up, debrief last week's shift, and plan the shift to come. Once in the gym, signing in takes Mary several minutes: she manually prints her name, signs her name, dates the sign-in sheet, and records her arrival time. Once signed in, Mary collects her cleaning supplies stored in the gym's staff closet. Armed with her neon solution spray and bucket of

\footnotetext{
${ }^{1}$ For anonymity and privacy, all names in this piece are pseudonyms and all potentially identifying details have been changed.
} 
threadbare rags, Mary navigates a maze of workout machines to reach the gym's yoga room. Finally there, she collects the mats she is to clean.

The fitness center is a community space. Each week a group meditation class is held in the yoga room during the hour Mary works. In order to reach the wall where most of the yoga mats lean, Mary quietly opens the door to the yoga room. She carefully tiptoes around the meditators who are scattered across the floor. With arms filled with mats, Mary walks to the far corner of the gym to the empty room that the gym uses as their childcare space, a playroom full of colorful, often broken toys. Twenty minutes after having signed-in, Mary begins her official job: with tattered rags and cleaning spray, she sanitizes the gym's yoga mats.

In her 2001 book, Nickel and Dimed: On (Not) Getting By in America, Ehrenreich asks, "How does anyone live on the wages available to the unskilled?" Mary's experience reveals what work can be like for workers who do "unskilled” work. In this essay I address Ehrenreich's question. I argue that workers like Mary navigate an employment system that at times systematically prevents them from having jobs or volunteer positions of dignity, positions in which employees are treated in ways that foster a sense of self-worth, pride, and self-respect (Sayer, 2007, p. 17). To build my argument, I draw on my experience working alongside adults who have impairments and who have minimum wage jobs. The examples that I offer are loosely based on encounters I had while supporting the work of adults who have impairments. With these examples, I illustrate how the conditions of the jobs made possible for these workers often render those jobs, and by extension the lives they make possible through the jobs' wages, undignified. I focus my discussion on manifestations of dignity in menial, "dirty" work context: "dirty" in one sense because the jobs often require physically dirty work, and "dirty" in another sense since these jobs are often stigmatized (i.e. morally and/or socially dirty since those doing 
the jobs are members of groups stigmatized in society: people who have impairments, people who are ex-felons, etc.). I draw on Sayer's key elements of dignity at work: that workers are respected as people, workers are not be treated merely as a means to others' ends, workers have autonomy, workers are not taking advantage of other workers' vulnerability, workers are trusted to act responsibly, workers are taken seriously and listened to, and workers do kinds of work that are not demeaning (p. 17).

Akin to the servers Ehrenreich discusses, waiting staff who spend a third of their job time engaging in "side work" that is invisible to customers, including sweeping, scrubbing, slicing, refilling, and restocking (2001, p. 17), unskilled workers who are adults who have impairments do side, or invisible work. This work is necessary, yet it is rarely if ever compensated for and in this way it is work for which they are penalized. Some of these individuals' impairments require them to engage in additional work that is tacked on to their official, paid duties. For example, in order for a worker like Mary to do her job effectively, she must complete tasks that other workers might not have to complete. In other cases, she must complete certain tasks differently (at a different pace, for instance) than other workers might complete them. Yet, much of the time, those tasks do not appear in job descriptions and/or are seldom included in her on-the-clock (i.e. paid) time at work. Mary, for instance, has difficulties with fine motor movement. Filling up her cleaning solution spray bottle is a task that can take her fifteen minutes on some days, or two minutes on others.

Surveilling Mary one day, the gym manager recognized that this task took Mary ten minutes to complete. The manager informed Mary that, because he could complete that task more quickly than she could and due to the fact that the gym prioritized getting the task done as quickly and as low-cost as possible, he would be taking over Mary's bottle-filling task from that 
day forward. He told Mary that this change was necessary because it would save the gym money. When it came to this official task, Mary was no longer able to exercise what Sayer calls "the kinds of powers we associate with being a capable adult, both basic ones - controlling our bodies - and 'higher' ones involving complex tasks, especially in social situations" (2007, p. 19). To Sayer, dignity concerns how workers treat other workers, and thus dignity "depends on both the actor and her others" (p. 19). Therefore, dignity is not simply about how an individual worker behaves. Stripping someone of an official job-assigned duty because a worker's impairment might influence how long that duty might take on a given day constitutes what Sayer calls a dehumanizing act (p. 19). Mary's experience illustrates how an unskilled worker who has impairments can be disrespected through dehumanization at work. Mary's experience also epitomizes the social model of disability. Mary's impairments do not dis-able her; the way others interact effectively dis-ables her.

The social model of disability holds that barriers, negative attitudes, and exclusion by society, on purpose or not, are the main causes of disability. According to Oliver, whereas impairment is something that has to do with one's body or mind, disability is something that has to do with physical or social barriers that lead to one's loss or limitation of opportunities to take part in every day life of the community on an equal basis with others (1981). When the gym manager decided that Mary's impairment meant a certain task took her longer than it might take someone else, and therefore Mary should be stripped of that duty, Mary experienced a loss of opportunity at work. In the every day life of her workplace, Mary was no longer on the same level as her co-workers. Mary's impairment did not disable her; her manager's response to, or managing of the potential effects of her impairment disabled her. Like Mary, a person who has impairments can be dis-abled in society through others' micro-aggressions, i.e. brief, sometimes 
everyday exchanges that "send denigrating messages to certain individuals because of their group membership" (Pierce, 1970; Paludi, 2012). Mary's case described above begins to exemplify this concept because, by changing her work duties, Mary's manager conveyed to Mary that because Mary's impairment influences how long a certain task might take her on a given day, Mary was evaluated as a worker no longer worthy of having the duty she was originally assigned.

Whereas Mary's case constitutes an instance in which a worker's dignity was not prioritized, Stu's case exemplifies how dignity for workers with impairments can, quite effectively, be fostered in employment environments. As the following example shows, this can happen through the treatment of a worker "not purely as a means to someone else's ends or as invisible, but as an end in oneself, a person in one's own right" (Sayer, 2007, p. 20).

For years, thirty-five year old Stu worked as a stockperson at a local grocery store. His parents curated, and his employers fostered his passion for musicals. Every weekday from noon until 3PM, Stu stocked the store's dairy shelves. As he did his job opening boxes of yogurt, milk, and butter, Stu serenaded customers. He sang them hit tracks from his all-time favorites, The Sound of Music, The Lion King, and The Wizard of $\mathrm{Oz}$. On a daily basis customers told management that they chose to shop at Stu's market instead of the less expensive grocery store only a block away because they loved that Stu sang to them. "Stu serenades me," they would tell the managers, "and it always makes me smile." To maintain dignity at work, workers require autonomy (Sayer, 2007, p. 17). At the grocery story, Stu's dignity remained intact when managers and customers alike encouraged his unique skills. As Stu did his job stocking shelves, he sang, and while he was at work, Stu had autonomy. 
According to Sayer, dignity at work also requires that workers do not take advantage of others' vulnerability (2007, p. 17). The servers with whom Ehrenreich (2001) worked in Key West worked for tips. This meant that they had to use whatever bits of autonomy they had to ply customers with "the illicit calories" that signaled their love (Ehrenreich, p. 20). However, to save money, managers limited the number of free croutons and sugar packets that a server was able to give a customer. Since servers' tips depend on a customer's satisfaction with their dining experience, and because that experience can of course be improved with extra croutons or chocolate sauce drizzles, when managers put limits on what kinds of "nice gestures" a server was able to extend to a customer they curbed servers' autonomy. In so doing, the managers failed to take into account the not very well paid servers' financial vulnerability.

Preconditions of dignity at work are always precarious, though they are especially precarious when durable inequalities of power exist (Sayer, p. 18). Coupled with Ehrenreich's servers example, Mike's case illustrates how the instrumental goals of organisations are often pursued at the expense of employees' well being (Sayer, p. 18).

Crying, with hands behind his back, and sitting cross-legged on the gift shop rug, thirtynine year old Mike sat waiting for his mom to pick him up to take him home. Police officers loomed over him. With loud, firm voices, they told Mike that his work for the day was over. They said that his mother was coming to drive him home where he should calm down and relax. Tears streaming, Mike told the officers that he was confused. "Why am I in trouble?" he asked. “All I did was dust. I told my helper to get off the phone. It's her job to help me! She's not supposed to be on her phone," he explained.

In this moment, Mike's well being as an employee was deprioritized, and his personhood was lost, abandoned. Mike's helper, his job coach at the time, worked for a vocational 
organization that discouraged job coaches from using their cell phone when they were coaching. In Mike's case, the instrumental goal of that vocational organization was pursued at the expense of the employee's well being (Sayer, 2007, p. 18). The person who was there to serve as Mike's helper, his job coach, asserted her authority. She did this by exercising power over Mike. When Mike reminded her that she was not supposed to be on her phone when she was being paid to coach him, his job coach chose to respond by calling the police to report that Mike was being aggressive with her.

Mike's case is similar to the Key West servers' not having been able to openly act in ways they know will help them earn more tips (Ehrenreich, 2001). Police physically restrained Mike because his job coach characterized his assertiveness, his attempt to be autonomous, as threatening and potentially violent. Mike called his job coach out when he recognized that her phone use while she was on the clock was influencing his productivity. By asserting himself in this way, Mike was engaging in self-protection. As Mike explained, his job required him to dust, vacuum, and sweep the entire gift shop in a certain amount of time, and to do that he needed his job coach's help. He told the police officers that this was important to him because he did not want to disappoint his boss by not finishing his assigned duties in the time he was given. When people with impairments exercise agency in certain ways, as Mike did, their action at times lead to authorities responding by disciplining them. For Mike, talking back to his job coach resulted in his job coach calling authorities, i.e. the police, and reporting him as being "threatening" to her. In response, the authorities arrived on scene and restrained Mike until his mother came to bring him home.

For dignity at work, workers must be trusted to act responsibly, be taken seriously, and be listened to (Sayer, 2007, p. 17). As an employee trying to complete his assigned duties on time, 
Mike was attempting to act responsibly, and was striving to perform as a good worker. Yet, in so doing, Mike was punished, his point was not taken seriously, and his action was criminalized. Fostering dignity of workers who have impairments requires more than providing these workers with "types of work which are not themselves demeaning" (Sayer, p. 17-18). The aim must also be to take seriously, listen to, and trust people who have impairments to act responsibly, regardless of how compelled an organization, manager, or job coach might feel to try to save face (Goffman, 1955).

Early on in my work alongside adults who have intellectual and developmental impairments, I learned a great deal about the deplorable working conditions that many workers face. These workers are frequently assigned as few hours as possible at their jobs; they are stuck doing work that no one else wants to do; and many receive minimal or no job benefits, job security, or possibilities for advancement. "The jobs our coaches are able to get for us have left me with no choice but to retire early," one worker told me once, "but I'm only 45 years old. I want to work," and after a pause, he added, "and that means that I have to do whatever job I'm given." For five years, that man's only paying job was to clean a salon once a week, at 6AM, for minimum wage, and was required to finish cleaning it in less than two hours. Two other days per week he volunteered, donating his time to his community. For the rest of his week, he stayed home with his mother.

This essay opens with, "The idea of duty in one's calling prowls about in our lives like the ghost of dead religious beliefs" (Weber, 1958, p. 182), words that encourage us to consider the idea of duty in one's calling. If duty in one's calling prowls about in our lives like a ghost, it haunts us. This is so because it is ever-present, and it is important to us. Weber's words lead us 
to contemplate what having a calling means, what significance work should have, and what the purpose is of the work that we do when we do our jobs. What is the aim? Why have a job?

At least part of an answer to these questions might be: we work because we want to contribute to our societies. We do our jobs to participate in our world, to do so alongside others, and to do so in helpful, dignified ways. Therefore, ethical meaning and dignity must always be treated as key factors in work. For, without dignity or ethical meaning in what we do when we work in order to contribute to our worlds, what are we left with, and what is the point?

Working conditions for people who do "unskilled" jobs must be improved. Perhaps we can start down this path by making greater efforts to treat dignity as a crucial dimension of meaning in work of all kinds, and in jobs people of all sorts do. In this piece I drew on the work of Ehrenreich (2001) and Sayer (2007), and addressed dignity as a dimension of meaning in work. In order to illustrate the need for opportunities for workers who have impairments, namely the potential benefits if work environments more effectively cultivate workers' self-respect, selfworth, and dignity, I used real life examples from my time working alongside adults who have impairments. Through this, I aimed to underscore the need for reform. As scholars, activists, and policy-makers work to more effectively curate dignity in working conditions of people with impairments, may dairy section serenades like Stu's be our fuel. 
Fine, "Songs From the Dairy Section"

CJDS 7.1 (March 2018)

\section{References}

Ehrenreich, B. (2001). Nickel and dimed: On (not) getting by in America. New York, NY: Metropolitan Books.

Goffman, E. (1955). On face-work: An analysis of ritual elements of social interaction. Psychiatry: Journal for the Study of Interpersonal Processes, 18(3), 213-231.

Oliver, M. (1981). A New Model of the Social Work Role in Relation to Disability. In J. Campling (Ed.), The Handicapped Person: a New Perspective for Social Workers? London, England: RADAR.

Paludi, M. A. (2012). Managing Diversity in Today's Workplace: Strategies for Employees and Employers. Westport, CT: Praeger.

Pierce, C. M. (1970). “Offensive Mechanisms.” In F. B. Barbour (Ed.), The Black Seventies (pp. 265-82). Boston: Porter Sargent.

Sayer, A. (2007). What dignity at work means. In S. C. Bolton (Ed.), Dimensions of Dignity at Work (pp. 17-29). London, England: Butterworth Heineman.

Weber, M. (1958). The Protestant ethic and the spirit of capitalism. T. Parsons (Tr.). New York, NY: Charles Scribner's Sons. 